\title{
A HISTORICAL MORPHOLOGY OF WESTERN KARAIM: THE - $p$ edi- PAST TENSE IN THE SOUTH-WESTERN DIALECT*
}

\author{
MICHAŁ NÉMETH \\ Institute of Linguistics, Jagiellonian University in Cracow \\ ul. marsz. Józefa Piłsudskiego 13, PL 31-110 Kraków, Poland \\ e-mail: michal.nemeth@gmail.com
}

\begin{abstract}
The present paper describes the - $p$ edi- past tense in Western Karaim - the first such attempt made in the available scholarly literature. It is important to note that the paper is based not only on philological data collected from manuscripts from the 18th-20th centuries, but also on field research conducted by the late Polish Turcologist, Józef Sulimowicz (1913-1973). His linguistic informants were Karaims from Halych.
\end{abstract}

Key words: historical morphology of Western Karaim, the - $p$ edi- past tense in Western Karaim, the - $p$ edi- past tense in Turkic, Western Karaim pluperfect tense.

\section{Preliminary Remarks}

Recently, a reviewer of Németh (2014) drew my attention to the South-western Karaim verbal form beribedin and advised me to juxtapose it with the $-p$ edi- ${ }^{1}$ past tense forms known from other Turkic languages - even though this past tense had never been mentioned before in Western Karaim grammatical descriptions. ${ }^{2}$ The above-mentioned

${ }^{*}$ This project was financed by the National Science Centre of Poland (Narodowe Centrum Nauki), grant number DEC-2011/03/D/HS2/00618. The author also benefited from grants 00497/ 12/FPK/NIMOZ and 02261/13/FPK/NIMOZ financed by The National Institute for Museums and Public Collection (Narodowy Instytut Muzealnictwa i Ochrony Zbiorów).

${ }^{1}$ As we can see in beribedin and shall observe in other data below, the intervocalic $-p$ - is voiced into $-b$ - in these forms (which is the usual practice in Karaim). Let us, however, refer to this construction as $-p$ edi- past for $-p$ is the original form of the suffix.

${ }^{2}$ See above all Grzegorzewski (1903, 1916-1918, 1917), Kowalski (1929), Zajączkowski (1931), Pritsak (1959a), Musaev (1964, 1977), Prik (1976), Berta (1998), Csató (1998), Aqtay (2009), Németh (2011a, 2011b). 
word (presented in sample sentence no. 1 in chapter 3 below) appears in the translation of a certain religious hymn copied in four prayer books from $\mathrm{Halych}^{3}$ by three different persons in the period between around 1778 and the $1850 \mathrm{~s}-1860 \mathrm{~s}$ (for details, see Németh 2014). Given that this form appears unchanged in at least four different copies it should definitely not be interpreted as a simple scribal error, and therefore classifying it as a - $p$ converb (expressing anteriority) of ber- 'to give' used with the auxiliary verb edi- is the most reasonable solution. Describing the semantic scope of this past tense in Karaim required, however, finding further philological data, which was a rather difficult task since the verbal form in question is very rare in Karaim. ${ }^{4}$ This article presents an analysis of the data available at the moment. Before, however, presenting them and formulating conclusions, let us consult the available Turkic linguistic material from a comparative perspective.

\section{The Turkic Linguistic Background}

The - $p$ edi-tense is used in a number of Turkic languages spoken in the Caucasus region, as well as in Central Asia. In particular, it is used in Karachay-Balkar, Kumyk, Nogai, Turkmen, Uzbek, Karakalpak, Kazakh, Kirghiz, and Uyghur. This list, however, may well be supplemented in the future - similar to what we can say regarding the only known comprehensive description on this matter, i.e. a subchapter in JuldaŠev (1965, pp. 188-198) ${ }^{5}$, which lacks any information regarding Kirghiz, Kumyk and, of course, Karaim. What, however, complicates our situation is that some of the grammatical descriptions of these languages offer contradictory interpretations of what the exact grammatical role of the $-p$ edi-forms is. For the time being, what we have at our disposal is the following:

\section{Karachay-Balkar -(y)b edi-}

- “Прошедшее незаконченное время. Эта форма употребляется тогда, когда то или иное совершенное действие еще не окончилось, или когда просто констатируется факт, что действие продолжалось, но нет указания на законченность его, нет указания на результат его" (Filolenko 1940, p. 68).

- "Прошедшее результативное время. [...] Область распространения этой формы в глагольной лексике ограничена узким кругом отдельных глаголов движения, процесса и состояния. [...] Что касается формы -ыб $\|$-б еди-, то еди-

\footnotetext{
${ }^{3}$ The catalogue numbers of these manuscripts are: JSul.III.03, JSul.III.63, JSul.III.69, and JSul.III.79.

${ }^{4}$ At this point see also the content of the Appendix below, where it is described by Józef Sulimowicz as a very rare category. After all, this tense is not very popular in other Turkic languages either; see our further remarks infra. šev (1988).

${ }^{5}$ At this point, it is worth mentioning that the analysed form is not at all mentioned in Teni-
} 
перемещает результат формы в плоскость прошедшего времени" (Urusbiev 1963, pp. 160-162).

Karakalpak -(y)p edi-

- Plusquamperfectum (Menges 1959, p. 478).

Kazakh -(y)b edi-

- “Прошедшее повъствовательное время" (Melioranskij 1894, p. 55).

- "Präsens-Präteritum. Die Handlung ist noch nicht beendet" (Räsänen 1957, p. 225).

- Plusquamperfectum (Menges 1959, p. 478).

Kirghiz - (y)bidy-

- “Давнопрошедшее” (Terent'ev" 1875, p. 148).

- "Настоящее-прошедшее, показывающее, что дъйствіе еще не вполнь кончилось" (Katarinskij 1906, pp. 88-89).

- Plusquamperfectum (Terent'ev"1875, p. 148; Menges 1959, p. 478).

Kumyk (dial.) -y(p) edi-

• “Предпрошедшее время” (Džanmavov 1967, p. 70).

Nogai -(y)p edi-

- Plusquamperfectum (Menges 1959, p. 478).

- "Low-focal pluperfect that expresses post-terminality and indirectivity" (CsatóKarakoç 1998, p. 339).

- Plusquamperfectum (Karakoç 2005, p. 21).

Uyghur -(i)p idi- - -(i)vidi

- "Perfect-like past" (Hahn 1998, p. 392).

- "Imperfectum plusquamperfecti” (Pritsak 1959b, p. 561).

- "Предпрошедшее время. [...] Данная временная форма выражает действие, которое произошло в недавнем прошлом, значение включает оттенок некоторого сожаления" (Nadžip 1960, pp. 96-97).

Uzbek (Kipchak) -(y)b edi-, -(y)p idy-

- “Прошедшее совершенное время" (Terent'ev" 1875, pp. 199-200).

- Plusquamperfectum (Menges 1959, p. 478). 
- "Предпрошедшее время. Эта форма выражает недавнее прошедшее время" (Kononov 1960, pp. 224-225).

- “Прошедшее повествовательное время” (Juldašev 1965, pp. 193-194).

It should be stated at the outset that most of the descriptions we have to rely on are short, sometimes even laconic, whereas the number of linguistic examples provided is limited and often presented without any context. Consequently, the picture we get does not answer all of the questions we might have. For instance, in the grammars of the vast majority of the languages listed above the - $p$ edi- past is described as a pluperfect tense, but no information is provided on the difference between the $-p$ edi- past and the widely used -gan edi-, the pluperfect usage of which (in most of the Turkic languages, and so in Karaim) leaves no doubts whatsoever. The only language in which the - $p$ edi-forms were not classified as a pluperfect tense is Karachay-Balkar, but we cannot treat this information without reservation for in this language this verbal category is reported to be extremely rare - see Urusbiev (1963, p. 160) with some statistical data provided - and hence its function might not be sufficiently described.

Additionally, there are four languages in which the discussed construction performs additional roles besides the pluperfect tense. However, all of them are described incoherently:

Firstly, in Kazakh it is referred to as pluperfect (Menges 1959; without any examples provided), as narrative past (see Melioranskij 1894, p. 55; without any context provided) and, however vague it may sound, as "Präsens-Präteritum", that is expressing an action that was not completed at the time being considered (Räsänen 1957, p. 225; without any context provided), i.e. what Räsänen most probably meant is an imperfective past tense. ${ }^{6}$ In other words, it seems as if Melioranskij, Räsänen, and Menges wrote about three completely different verbal categories. According to G. Aqtay (personal communication), the Kazakh - $p$ edi- verbs serve to denote an event that preceded another one that happened in the past, whereas the negated - $p$ edi-forms express an event that was expected by the speaker, but eventually did not take place. ${ }^{7}$ Kirchner's (1998) article lacks this category.

Secondly, Terent'ev" (1875, p. 148) and Menges (1959, p. 478; without providing any specific data) classify the - $b$ edi- past in Kirghiz as a pluperfect tense, whereas, as we mentioned above, in Katarinskij's (1906, pp. 88-89) short Kirghiz manual it is described as a "present-past" tense that expresses an action not yet completed.

\footnotetext{
${ }^{6}$ What Räsänen (1957, p. 225) quotes is: “(Orenb. Gr. 88-9): b-Konv. edi: kara-b edi-m, kara-b ediๆ usw.". The Literaturverzeichnis - either in Räsänen (1957) or in Räsänen (1949) - does not contain the explanation of "Orenb. Gr." The abbreviation "Orenb." probably means Orenburg (Russ. Оренбург), a city in the Orenburg Oblast near the boarder with Kazakhstan, whereas "Gr." most probably stands for Germ. Grammatik. Taking these facts together it appears likely that what Räsänen really refers to is in fact Katarinskij's (1906) Kirghiz Grammar printed in Orenburg (see our remarks below). This is all the more likely as in this grammar the $-b$ edi-tense is presented on pages 88-89. I thank Dr. Tomasz Majtczak (Cracow) for this suggestion.

${ }^{7}$ I am grateful to Dr. Gülayhan Aqtay (Poznań), a native speaker of Kazakh, for her kind help in this matter.
} 
Unfortunately, no exemplification of usage or Russian translation of the conjugation presented there is provided by Katarinskij (1906).

Thirdly, in Uyghur the verbal category in question is described, on the one hand, as a pluperfect that refers to actions completed recently - compared to the time being considered (Nadžip 1960, pp. 96-97). On the other hand, it is termed imperfectum plusquamperfecti by Pritsak (1959b, p. 561), but the latter article provides no further explanations whereas the linguistic samples cited above point rather to single, non-habitual, completed actions without any imperfective meaning or relative chronology of events expressed. Therefore, it is not entirely clear why it is called either imperfectum, or plusquamperfecti. Furthermore, Hahn (1998, p. 392) defines it as a "perfect-like past", the exact meaning of which also remains obscure. The examples provided by the latter author lack any informative context and are translated into English using the present perfect tense. In other words: it seems as if Pritsak and Hahn had doubts about the exact role of the analysed construction as they did not have enough data to describe it properly.

Lastly, in Uzbek the $-b$ edi-forms are described as expressing the pluperfect (Menges 1959, p. 478; without, again, any linguistic data specified), as well as a pluperfect that refers to events recently completed (Kononov 1960, pp. 224-225), as a perfective past (Terent'ev" 1875, pp. 199-200) and, finally, as a narrative past (Juldašev 1965, pp. 193-194).

It is important to note that the - $p$ edi- past must not be confused either with the $-p t y(r) 3 \mathrm{rd} \mathrm{sg}$. forms that describe a non-evidential action or with the $-p t y(r)$ ediconstruction. The phonetic shape of these markers may vary in the relevant Turkic languages, but their structure is evident: in the former it is the $-p$ converb used with the -tyr -tur $\sim$-tir $\sim$-tür suffix (that originates from the verb tur- 'to stand'; the syllable-closing $-r$ happens to be elided), whereas in the latter it is the same marker used with the verb edi- (the simple past form of $e$ - 'to be'). These categories were linked to the - $p$ edi-forms, for example, in Džanmavov (1967, p. 70) or Karakoç (2005, p. 21): the former author identifies the Kmk. - $p$ tur-forms with the - $p$ edi-verbal category, whereas the latter treats the -ypty edi- marker as its unabbreviated form. Both constructions are widespread in the Turkic languages, but absent in Western Karaim. ${ }^{8}$

Table 1 (see page 220) summarises what has been said above.

According to Juldašev's (1965, pp. 188-198) description, the analysed verbal category is mainly used for two purposes in the Turkic languages in general. According to Juldašev, in the vast majority of cases it is used to express the relative chronology of two (or more) events. More precisely, it expresses an action - predominantly a completed action - that usually precedes another one. ${ }^{9}$ Less characteristically, it may

${ }^{8}$ In Crimean Karaim only the - $p t y(r)$ 3rd sg. forms were in use and expressed non-evidential or reported actions, see Aqtay (2009, Vol. I, p. 42). It is important to note that the manuscript edited by Aqtay (2009) was strongly influenced by Crimean Ottoman Turkish.

${ }^{9}$ For examples (from the Uzbek language) in which forms in - $p$ edi- refer to an event or action that follows another, see Juldašev (1965, p. 191). 
Table 1. The roles played by -p edi-forms in Turkic languages as described in the grammars below

\begin{tabular}{||l||c|c|c|c|c|c|c|c||}
\hline & Krč.-Blk. & Kklp. & Kzk. & Kirg. & Kmk. & Nog. & Uyg. & Uzb. \\
\hline \hline Pluperfect & & + & + & + & + & + & + & + \\
\hline Pluperfect for recent events & & & & & & & + & + \\
\hline Perfect-like past & & & & & & & & + \\
\hline Imperfective pluperfect & & & & & & & + & \\
\hline Imperfective past & + & & + & + & & & & \\
\hline Resultative past & + & & & & & & & \\
\hline Narrative past & & & + & & & & & + \\
\hline
\end{tabular}

also be used in narration and this is, according to Juldašev, its second role (and secondary at the same time). In the latter case, however, it requires a proper textual and grammatical context, e.g. the use of proper adverbs, style, etc. The remaining roles attributed to this category (e.g. plusquamperfectum, evidentiality, expressing a single action, expressing completed actions, expressing an action completed a long time ago, etc.), are, according to Juldašev (1965, pp. 188-198), aspects that often accompany its contextual role, but do not constitute an inherent part of its semantic field. In fact, Juldašev's lengthy argumentation and his conclusions seem quite apt and convincing and fits in quite well with the Karaim material that we have at our disposal.

\section{The Available Western Karaim Data - Examples}

Eventually, I managed to find two other occurrences of this past tense in a draft of a private letter written in Lutsk Karaim and Hebrew in the first half of the 19th century (JSul.I.40/4), additional three of them in one sentence in a manuscript (JSul.I.50-9) from 1865 containing a paraliturgical poem, and, thanks to the help of Anna Sulimowicz (Warsaw), further three examples in the notebook of her father (see Appendix), the late Polish Turcologist Józef Sulimowicz (1913-1973) with some additional, extremely valuable explanations of their use provided by him and the native speakers he interviewed. ${ }^{10}$ Altogether, therefore, I have found the verbal form in question recorded in nine sentences. I have presented them below in a unified transcription and with the context provided. The $-p$ edi- forms and their equivalents in the translation are underlined.

\footnotetext{
${ }^{10}$ My warm thanks are due to Anna Sulimowicz (Warszawa) for making these additional sources accessible for me.
} 


\section{Example 1}

- Da dag்yn čeber jerimden de ki ülüš beribedin any mana sürdün meni andan da zanlyklar arasyna tozdurdun ulanlarymny. "And even from the pleasant land of mine which you [i.e. God - M.N.] had given me as a legacy you have cast me out and among kingdoms you have scattered my children' (JSul.III.63, f. $35 \mathrm{v}^{\mathrm{o}}$; around 1778).

\section{Example 2}

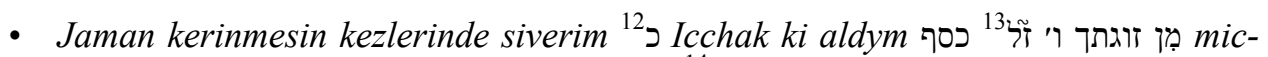

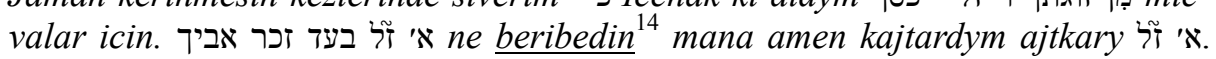
'May it not appear to be [something] bad in your eyes my beloved honourable Icchak that I took from your wife 5 silver złoty for offerings. I have already given back the 1 zloty for the memory of your father, amen, that you had given me' (JSul.I.40/4, f. $1 \mathrm{r}^{\mathrm{o}}$; the 1 st half of the 19th century).

\section{Example 3}

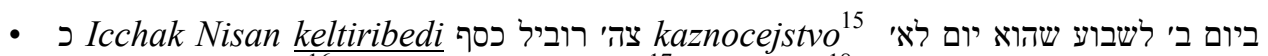
במספרם $\tan ^{19}$ son ali hanuz keltirmedi. 'The honourable Icchak Nisan had brought 95 silver roubles to the revenue office on the second day of the week that is the 31 st day according the their counting [= Julian calendar] in the evening, but the head of the revenue office did not want to take it and [Icchak Nisan] said that he would bring it after the New Year, but he has not brought it yet' (JSul.I.40/4, f. $1 \mathrm{r}^{\mathrm{o}}$; the 1 st half of the 19th century).

${ }^{11}$ In JSul.III.03, JSul.III.69, and JSul.III.79 this sentence is very much the same (the differences are underlined): Da dagyn čeber jerimden de ki ilis beribedin any mana sirdin meni andan da

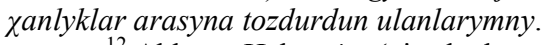

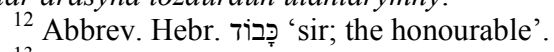

${ }^{13}$ An abbreviation of Pol. zloty 'Polish currency'.

${ }^{14}$ This word is one of the three that are vocalised in the text: ביריבידידין

$15<$ Russ. (arch.) казначейство 'revenue office; financial authority in pre-revolutionary Russia supervising the treasury and administering the state incomes and expenses' (SRJa II 15-16) $\leftrightarrow[=$ a blend with $]$ Pol. kaznodziejstwo 'preaching'. In South-western Karaim the word was widely used in this form, see Németh (2011a: 294).

${ }^{16}$ The word is vocalised: כֵיצְקוּרוּן 2. late' (KarRPS 331).

${ }^{17}<$ Russ. (arch.) казначей 'revenue officer', see e.g. Černych (1993) I 368 s.v. казна, $\leftrightarrow$ Pol. kaznodzieja 'preacher'. auxiliary verb.

${ }^{18}$ SWKar. prinjatme 'to take, to accept' $\leftarrow$ Russ. принять id. or Ukr. приняти id. + etme $19<$ Pol. dial. Nowyj Rok 'New Year' with the ablative case suffix. 


\section{Example 4}

- Paroda kul edim, anda tynmabedim, dušman Haman ol jaman koluna tišibedim, eksileride ičin men oruč tutubedim, Paro batty, Haman katty, berdi ma ne kledim. 'I was a servant at the Pharaoh, there I had had no rest, I had fallen into the evil hands of the enemy Haman, for both I had fasted, the Pharaoh sank, Haman stiffened, he gave me what I wanted' (JSul.I.50-9: $2 \mathrm{r}^{\circ}$; from 1865).

\section{Example 5}

- Mana kerined' kim of kelibedi i aldy sonu. 'It seems to me that he had come and taken this' (Sulimowicz 1969; 20th century). - See Appendix.

\section{Example 6}

- Buvalo barybedim mamaba saharha. 'There were times when I went [or: I used to go] with mum to the town' (Sulimowicz 1969; 20th century). - See Appendix.

\section{Example 7}

- Kacanes, davno Karajłar ystyrynybediler zerette. 'Formerly, long ago, Karaims assembled [or: used to assemble] at the cemetery' (Sulimowicz 1969; 20th century). - See Appendix.

\section{Analysis}

It is evident from the first five Karaim sample sentences that the $-p$ edi-forms refer to a single, already completed action that occurred in the past prior to another action which also took place in the past. The latter action is always expressed with the $-d y$ simple past tense and it tends to express the "main" action of the sentence: the $-p$ ediverbs tend to be semantically subordinated to it and serve to specify the circumstances in which the main action occurred. Unlike Uzbek, we have no sufficient data at our disposal to judge whether the - $p$ edi- past in Karaim could also express an action that took place after the main event.

At first sight, the - $p$ edi-forms in examples $1-5$ also seem to report a non-witnessed event, ${ }^{20}$ but it remains an open question whether this particular shade of meaning of the $-p$ edi- construction comes as an inherent feature or simply results from contextual implications. The close interconnection between "postterminality" and

${ }^{20}$ In linguistics in general this grammatical category is, among others, also referred to as the inferential mood, the narrative mood, the renarrative mood, indirective, non-evidentiality, modus auditivus, imperceptivus, narrativus, relativus, etc., in the field of Turcology see e.g. Johanson (2000, 2003). 
a reference to a non-witnessed event or action has been disputed at length by Johanson (2000, pp. 63-64).

What is not specified by these forms is whether the action in question ended a long time before the chronologically later one or whether it took place just before it. As far as this aspect is concerned, the biggest contrast is between examples 1 and 5; in the former the verb beribedin refers to God who gave the land as a legacy to the people of Israel, whereas in the latter, according to the speaker, the action expressed with kelibedi took place almost simultaneously with the second event mentioned in the sentence.

At the same time, it is also evident that examples 6-7 do not fit in with the above description. Both sentences contain only one verb and therefore it is out of question that the $-p$ edi-constructions used in them might express a chronologically earlier action. Secondly, the $-p$ edi- verb used in sample sentence 6 reports a witnessed event - it stands in the $1 \mathrm{st} \mathrm{sg}$. form.

The content of sample sentences 6 and 7 suggests that the $-p$ edi-forms used in them refer to recurring habitual ${ }^{21}$ actions that took place in the past and that is to, most likely, the distant past - cf. the use of adverbs buvalo $(<\mathrm{Ukr}$.) 'there were times', kacanes 'formerly', and davno (< Pol., Russ., or Ukr.) 'long ago'. So if what Rachela Eszwowicz said is true (see Appendix), we must assume that the $-p$ edi-past served to express two different grammatical meanings: a kind of pluperfect (regardless of the chronological distance between the two actions mentioned in a sentence) and a perfect-like tense expressing habitual actions that took place in the distant past. As far as the latter is concerned, it resembles the role of the Karaim imperfect (which, as we mentioned, also served to express habitual actions), but the examples we have at our disposal point rather to a perfective than to an imperfective use. The imperfective meaning of the $-p$ edi- forms would be quite surprising if we take into consideration the fact that the $-p$ converb denotes anteriority and that there are no supportive examples for such a description in Turkic languages. Although Filolenko (1940, p. 68) has described the $-b$ edi- forms in Balkar as an imperfectum, he did not provide any convincing philological data to prove this and, later, his interpretation was criticised and rejected by Juldašev (1965, p. 189), who presented linguistic evidence (among other examples from Filolenko's work) to prove that the relevant Balkar tense refers to a completed action. In the same year, i.e. in 1963, Urusbiev (1963, p. 160) classified the $-b$ edi-construction in Karachay-Balkar as a resultative past tense. Additionally, it was Räsänen (1957, p. 225) who, after Katarinskij (1906, p. 88) named the -p editense Präsens-Präteritum (generally, for Turkic) and described it with a short Die

${ }^{21}$ This seems also to be somewhat supported by what Mr. Isakowicz said and investigated by Józef Sulimowicz (see Appendix): he claimed that the $-r$ edi-imperfect (which was used in Karaim to express habitual actions) and the - $p$ edi-past could be used interchangeably. However, what he said, i.e. Pol. można mówić „, tak i tak” 'one may say so and so' (see Appendix), can also mean: 'both forms are correct.' And, indeed, the model he gave (i.e. sample sentence no. 5) in response to J. Sulimowicz's request to provide examples for his statement, clearly points to a pluperfective use (as J. Sulimowicz also noted), which makes us doubt the alleged interchangeable use of the two tenses in question. 
Handlung ist noch nicht beendet. However, he provided only one Kazakh (or, in fact, Kirghiz - in the early Turcological publications Kirghiz and Kazakh happened to be confused or treated as variants of one idiolect) example without any further context and there is no other grammatical description either of Kazakh or of Kirghiz that would support his statement. Finally, Pritsak (1959b, p. 561) termed the respective tense in Uyghur as imperfectum plusquamperfecti, but, as has already been mentioned above, all the examples he gave refer to perfective actions.

The idea, first conceived by Juldašev (1965, pp. 193-194), of treating the $-p$ ediforms in sentences 6 and 7 as examples of a past tense used for narrative purposes (regardless of imperfective or perfective meaning) also seems tempting. In this case the habitual shade of meaning would only be implied by the context. This seems to be supported by the use of adverbs characteristic of narration. Still, a perfect-like tense referring to actions that took place in the distant past seems to be much closer to a pluperfect than to a narrative past, which makes the latter interpretation somewhat less probable.

Another possible interpretation of the use of the verb forms in sentences 6 and 7 is that they also express a pluperfective meaning, whereas the chronologically earlier actions were mentioned in the sentences following the documented ones, i.e. in the missing context. This assumption must, however, remain speculative, for it cannot be, for the time being, confirmed (cf. footnote 27 below).

\section{Final Conclusion}

All in all, the Western Karaim - $p$ edi- past was semantically very close to the -gan edi- (>-gandy-) pluperfect, and to a lesser degree, also to the $-r$ edi- $(>-r d y-)$ imperfect. Apparently, as a consequence of this semantic closeness of tenses the grammatical category in question became redundant, and therefore, was extremely rarely used. In the final analysis, it seems that Plusquamperfectum II might be an appropriate and informative term for what we have in sample sentences $1-5,{ }^{22}$ even though it would not entirely cover the role played by the $-p$ edi-forms in examples $6-7$. We must, however, bear in mind that an exact analysis of the latter two sentences is impossible given the lack of further context.

\section{Appendix}

Below the reader will find Józef Sulimowicz's notes concerning the - $p$ edi- verbal form along with its English translation. The fragment in question contains various observations made and answers received during a conversation with Samuel Isakowicz

${ }^{22}$ With the reservation that, given the shortage of examples available, we do not know whether this category may have been used for expressing that something happened after another action - as is the case in Uzbek. The possibility that such an attestation will come to light is rather low. For instance, Juldašev (1965, pp. 193-194) quotes only Uzbek examples for this use of the category. 
and his wife Maria (both from Halych) that most probably took place in Gdańsk on 28th November 1969. The pages of the notebook are not numbered.

\section{Formy na -yp, -up, -ip, -p edi}

Użycie przeze mnie w rozmowie formy ke'libedi, a'lybedi ${ }^{23}$ nie zwróciło uwagi żadnego z małżonków Isakowiczów, chociaż sami używali formy ke'liredi, a'lyredi. Kiedy zwróciłem im na to uwagę, odpowiedzieli, że można mówić ,tak i tak”. Na moją prośbę o przykład użycia formy -ybedi: „ma'na keri'ned' kim of ke'libedi i a'tdy so'nu, to znaczy: zdaje mi się, że on byt przyszedt, wziąt to i to (coś tam)".

[Z wyjaśnień Isakowicza wynikałoby, że form na -ybedi używano (rzadko) dla wyrażania czynności wykonanej wcześniej niż została dokonana następna $\mathrm{z}$ nią związana, albo też formy te wyrażały plusquamperfectum. Formy te w użyciu Racheli Eszwowicz (zwanej Ho'risnyj Rachuni, tj. Rachunia z Góry (= dzielnica Halicza)) wyrażały częstotliwość czynności w czasie przeszłym, np.: buwało bary'bedim ma'ma-

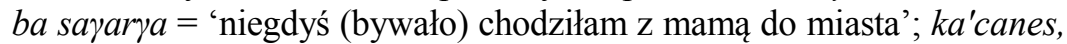
dawno Karajłar ystyrynybediłer zerette = 'niegdyś, dawniej Karaimi zbierali się na cmentarzu'.] [... $]^{24}$

Formy na -'ybedi, -ibedi, -bedi być może $<-y p$, -ip, - $p$ berdi,

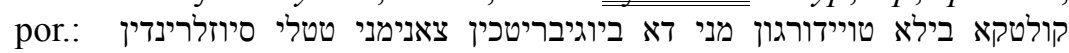

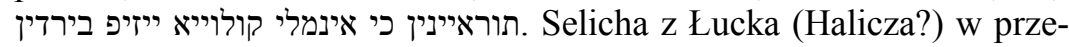
kładzie Nisana z Trok s. Symxy.

Translation:

My use of the forms ke'libedi, a'lybedi in our conversation ${ }^{25}$ did not attract the attention of Mr. and Mrs. Isakowicz, ${ }^{26}$ even though they themselves used the forms ke'liredi, a'lyredi. When I drew their attention to this fact, they answered that one may say so and so. In answer to my request to give an example of its use [they said]: " $m a$ 'na keri'ned' kim of ke'libedi i a'tdy so'nu", which means "it seems to me that he had come and took this and this (something)".

${ }^{23}$ An apostrophe (') in Józef Sulimowicz's notes indicates the stress (it then precedes the accented syllable) or palatality (it then follows the relevant consonant).

${ }^{24}$ The fragment omitted here concerns a completely different topic.

${ }^{25}$ Józef Sulimowicz was a native-speaker of Halych Karaim. For his curriculum vitae see Dubiński (1973) and Sulimowicz, A. (2013, pp. 4-10).

${ }^{26}$ Samuel Ickowicz (= Isakowicz as used by J. Sulimowicz), the son of Icchak, born 1902 in Załukiew (today: a district of Halych), died 1980 in Oliwa (a district of Gdańsk), was an engine driver, amateur actor and poet. His wife was Maria Ickowicz née Szulimowicz, the daughter of Icchak, born 1906 in Halych, died 1973 in Oliwa. 
[From Mr. Isakowicz's explanations it appears to transpire that the $-y b e d i$ forms were (rarely) used to express an action performed prior to another one connected with it or that these forms were used to express the pluperfect tense. These forms as used by Rachela Eszwowicz ${ }^{27}$ (called Ho'risnyj Rachunia, i.e. Rachunia from Hora (= a district of Halych)) expressed recurring actions in the past, e.g. buwało bary'bedim ma'maba sayarya = 'there were times when I went with mum to the town'; ka'canes, dawno Karajłar ystyrynybediłer zerette = 'formerly, long ago, Karaims assembled at the cemetery.']

The forms -'ybedi, -ibedi, -bedi perhaps $<-y p$, -ip, -p berdi, cf.: Koltka byla tojdurgun meni da bögevretkin zanymny tatly sözlerinden Torajnyn ki inamty koluja jazyp berdin ['Satiate me with prayer and water my heart with the sweet words of your Torah that you have written with your trusted hand']. A selichah [= penitential poem or prayer - M.N.] from Łuck (or Halicz?) translated by Nisan ha-Troki, the son of Simcha.

\begin{abstract}
Abbreviations
arch. $=$ archaic; Germ. $=$ German; Kirg. $=$ Kirghiz; Kklp. $=$ Karakalpak; Kmk. $=$ Kumyk; Krč.Blk. $=$ Karachay-Balkar; Kzk. $=$ Kazakh; Nog. $=$ Nogai; Pol. $=$ Polish; Russ. $=$ Russian; SWKar. $=$ South-western Karaim; Ukr. = Ukrainian; Uyg. = Uyghur; Uzb. = Uzbek
\end{abstract}

\title{
References
}

Aqtay, G. (2009): Eliyahu ben Yosef Qulcı's Anthology of Crimean Karaim and Turkish Literature. Critical Edition with Introduction, Indexes and Facsimile. Vols 1-2. İstanbul (Y1ldiz Dil ve Edebiyat Dizisi 8).

Berta, Á. (1998): West Kipchak Languages. In: Johanson, L.-Csató, É. Á. (eds): The Turkic Languages. London-New York, pp. 301-317.

Csató, É. Á. (1998): Über die finiten Verbformen des gesprochenen Nordwest-Karaimischen. In: Taube, E.-Demir, N. (eds): Turkologie heute - Tradition und Perspektive. Wiesbaden (Veröffentlichungen der Societas Uralo-Altaica 46), pp. 47-53.

Csató, É. Á. - Karakoç, B. (1998): Noghay. In: Johanson, L. - Csató, É. Á. (eds): The Turkic Languages. London-New York, pp. 333-343.

Černych, P. Ja. (1993): Istoriko-ètimologičeskij slovarb sovremennogo russkogo jazyka. Vols 1-2. Moskva. (Reprinted in 2001.)

Dubiński, A. (1973): Józef Sulimowicz. Przegląd Orientalistyczny Vol. 88, No. 4, pp. 365-366.

Džanmavov, Ju. D. (1967): Deepričastija v kumykskom literaturnom jazyke. Moskva.

Filolenko, V. I. (1940): Grammatika balkarskogo jazyka. Fonetika i morfologija. Naĺčik.

${ }^{27}$ Rachela Eszwowicz (unmarried), the daughter of Simcha, born 1869 in Halych, died 1946. It remains an open question when J. Sulimowicz collected linguistic data from her. The quoted fragment in the notebook evidently originates from the late 1960s or early 1970 s. 
Grzegorzewski, J. (1903): Ein türk-tatarischer Dialekt in Galizien. Vokalharmonie in den entlehnten Wörtern der karaitischen Sprache in Halicz. [Mit Einleitung, Texten und Erklärungen zu den Texten]. Sitzungsberichte der kais[erlichen] Akademie der Wissenschaften in Wien. Philosophisch-historische Klasse Vol. 146, pp. 1-80.

Grzegorzewski, J. (1916-1918): Caraimica. Język Łach-Karaitów [Caraimica. The Language of the Lach Karaites]. Rocznik Oryentalistyczny Vol. 1/2, pp. 252-296.

Grzegorzewski, J. (1917): Narzecze południowe Karaitów polskich czyli t. zw. Łach-Karaimów [The southern dialect of the Polish Karaites that is of the so-called Lach Karaims]. Sprawozdania z czynności posiedzeń Akademii Umiejętności w Krakowie Vol. 22, No. 3, pp. 2-6.

Hahn, R. F. (1998): Uyghur. In: Johanson, L. - Csató, É. Á. (eds): The Turkic Languages. LondonNew York, pp. 379-396.

Johanson, L. (2000): Turkic Indirectives. In: Johanson, L. - Utas, B. (eds): Evidentials. Turkic. Iranian and Neighbouring Languages. Berlin-New York.

Johanson, L. (2003): Evidentiality in Turkic. In: Aikhenvald, A. Y. - Dixon, R. M. W. (eds): Studies in Evidentiality. [Chapter 12]. Amsterdam-Philadelphia (Typological Studies in Language 54), pp. 273-290.

Juldašev, A. A. (1965): Analitičeskie formy glagola v tjurkskich jazykach. Moskva.

Karakoç, B. (2005): Das finite Verbalsystem im Nogaischen. Wiesbaden (Turcologica 58).

KarRPS = Baskakov, N. A. - Šapšal, S. M.-Zajončkovskij, A. (eds) (1974): Karaimsko-russkopol'skij slovar'. Stownik karaimsko-rosyjsko-polski [Karaim-Russian-Polish dictionary]. Moskva.

Katarinskij, V. V. (with the assistance of Bachtigireev, A. K.) (1906): Grammatika kirgizskago jazyka. Fonetika, ètimologija i sintaksis". Orenburg".

Kirchner, M. (1998): Kazakh and Karakalpak. In: Johanson, L. - Csató, É. Á. (eds): The Turkic Languages. London-New York, pp. 318-332.

Kononov, A. (1960): Grammatika sovremennogo uzbekskogo literaturnogo jazyka. Moskva-Leningrad.

Kowalski, T. (1929): Karaimische Texte im Dialekt von Troki. Kraków (Prace Komisji Orjentalistycznej Polskiej Akademji Umiejętności 11).

Melioranskij, P. M. (1894): Kratkaja Grammatika kazak"-kirgiskago jazyka. Čast' 1. Fonetika i Ètimologija. Sanktpeterburg”.

Menges, K. H. (1959): Die aralo-kaspische Gruppe. In: Deny, J. - Grønbech, K. - Scheel, H. - Velidi Togan, Z. (eds): Philologiae Turcicae Fundamenta. Vol. 1. Wiesbaden, pp. 434-488.

Musaev, K. M. (1964): Grammatika karaimskogo jazyka. Fonetika i morfologija. Moskva.

Musaev, K. M. (1977): Kratkij grammatičeskij očerk karaimskogo jazyka. Moskva.

Nadžip, È. N. (1960): Sovremennyj ujgurskij jazyk. Moskva.

Németh, M. (2011a): Unknown Lutsk Karaim Letters in Hebrew Script (19th-20th Centuries). A Critical Edition. Kraków (Studia Turcologica Cracoviensia 12).

Németh, M. (2011b): Zwięzła gramatyka języka zachodniokaraimskiego z ćwiczeniami [A concise grammar of North-western Karaim with exercises]. Poznań (Prace Karaimoznawcze 1).

Németh, M. (2014): A Historical Phonology of Western Karaim: Alveolars and Front Labials in the South-western Dialect. Studia Linguistica Universitatis Iagellonicae Cracoviensis Vol. 131, No. 3, pp. 247-267.

Prik, O. Ja. (1976): Očerk grammatiki karaimskogo jazyka (krymskij dialekt). Machačkala.

Pritsak, O. (1959a): Das Karaimische. In: Deny, J.-Grønbech, K.-Scheel, H. - Velidi Togan, Z. (eds): Philologiae Turcicae Fundamenta. Vol. 1. Wiesbaden, pp. 318-340.

Pritsak, O. (1959b): Das Neuuigurische. In: Deny, J. - Grønbech, K. - Scheel, H. - Velidi Togan, Z. (eds): Philologiae Turcicae Fundamenta. Vol. 1. Wiesbaden, pp. 525-563. 
Räsänen, M. (1949): Zur Lautgeschichte der türkischen Sprachen. Helsinki (Studia Orientalia 15).

Räsänen, M. (1957): Materialien zur Morphologie der türkischen Sprachen. Helsinki (Studia Orientalia 21).

SRJa = Evgeneva, A. P. -Knjaz'kova, G. P.-Rozanova, V. V.-Matveev, I. I.-Kutina, L. L.Zamkova, V. V. (eds) (1957-1961): Slovar' russkogo jazyka. Vols 1-4 (vol. 1: 1957; vol. 2: 1958; vol. 3: 1959; vol. 4: 1961). Moskva.

Sulimowicz, A. (2013): Mieczek i Siunek [Mieczek and Siunek]. Awazymyz Vol. 38, No. 1, pp. $4-13$.

Sulimowicz, J. (1969): see Sulimowicz (1969) in Handwritten Sources below.

Tenišev, È. R. (ed.) (1988): Sravnitel'no-istoričeskaja grammatika tjurkskih jazykov. Morfologija. Moskva.

Terent'ev", M. (1875): Grammatiki: tureckaja, persidskaja, kirgizskaja i uzbekskaja. Kniga pervaja. Sanktpeterburg".

Urusbiev, I. Ch. (1963): Sprjaženie glagola v karačaevo-balkarskom jazyke. Čerkessk.

Zajączkowski, A. (1931): Krótki wykład gramatyki języka zachodnio-karaimskiego (narzecze tuckohalickie) [A brief outline of the grammar of Western Karaim (Lutsk-Halych dialect)]. Łuck.

\section{Handwritten Sources}

JSul.I.40/4 = Handwritten draft of a private letter on financial and fiscal matters issued in Lutsk in Hebrew and South-western Karaim in the first half of the 19th century. Kept in a private archive in Warsaw.

JSul.I.50-9 = A manuscript from 1865 containing a liturgical poem (so called zemer) written in South-western Karaim (incipit: Kicli bijim kiplihim) and its translation into Hebrew (incipit:

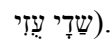

JSul.III.03 = Handwritten, vocalised additions in Hebrew and South-western Karaim from ca. 1778 added to a printed prayer book (in Hebrew) from 1736/1737. Kept in a private archive in Warsaw.

JSul.III.63 = Handwritten, vocalised additions in Hebrew and South-western Karaim from the 19th century added to a printed prayer book (in Hebrew) from 1804/1805. Kept in a private archive in Warsaw.

JSul.III.69 = Handwritten, vocalised prayer book in Hebrew and South-western Karaim from Halych from the period 1851-1866. Kept in a private archive in Warsaw.

JSul.III.79 = Handwritten, vocalised prayer book in Hebrew and South-western Karaim from Halych from the period 1851-1866. Kept in a private archive in Warsaw.

Sulimowicz (1969) = A notebook of Józef Sulimowicz with notes in Polish on Karaim grammar and lexicography. Kept in a private archive in Warsaw. 